ECOLOGICA, Vol. 28, No 103 (2021), 451-458

https://doi.org/10.18485/ecologica.2021.28.103.16

Originalni naučni rad

UDC: 338.48-44(1-22):[616.98:587.834](497.11)

\title{
Uticaj pandemije COVID-19 na održivi razvoj ruralnog turizma u turističkoj regiji Zapadna Srbija
}

\section{The impact of the COVID-19 pandemic on sustainable development of rural tourism in the West Serbia tourist region}

\author{
Marina Vesić ${ }^{1}$, Jelena Bolović ${ }^{2 *}$, Nikola Todorović ${ }^{3}$, Sanja Pavlović ${ }^{4}$ \\ 1,3,4Univerzitet u Beogradu, Geografski fakultet, Beograd, Srbija / \\ University of Belgrade, Faculty of Geography, Belgrade, Serbia \\ ${ }^{2}$ Turistička organizacija Požega, Srbija / Tourism Ogranisation Pozega, Serbia \\ *Autor za prepisku / Corresponding author
}

Rad primljen / Received: 08.12.2020, Rad prihvaćen / Accepted: 04.08.2021.

Sažetak: Održivi turizam, ostvaren je u skladu sa društvenim i privrednim načelima, uz uvažavanje okruženja i kultura. Evidentan je značaj lokalnih zajednica u ruralnim sredinama i njihovo pravo na održivi razvoj turizma. Međutim, pandemija Covid-19 uslovila je rapidno smanjenje turističkih kretanja i neizvesnost oporavka turističke privrede. Istraživanje za potrebe ovog rada obavljeno je pomoću anketnog upitnika, koji je poslat na adrese ugostiteljskih objekata u ruralnim sredinama turističke regije Zapadna Srbija. Anketni upitnik osim opštih informacija, sadrži set pitanja koja se odnose na turiste i perspektive sagledane sa aspekta pružalaca usluga. Ciljevi istraživanja su identifikacija trenutnih posledica pandemije i upoređivanje poslovanja ugostiteljskih objekata u ruralnom turizmu pre i tokom pandemije Covid-19, uzimanjem u obzir principa održivosti. Rezultati istraživanja ukazuju na jačanje uloge domaćeg turizma tokom perioda pandemije, ali i na perspektive opstanka pojedinih ugostiteljskih objekata. U metodološkom smislu, kvantitativni i kvalitativni prikaz podataka, omogućava uvid u najjače i najslabije izazove sa kojima se ruralni turizam u istraživanom prostoru suočava, što predstavlja praktične implikacije za nosioce turističke ponude ovog kraja Srbije.

Ključne reči: održivost, ruralni turizam, Covid-19, Zapadna Srbija.

\begin{abstract}
Sustainable tourism is developed in accordance with social and economic principles, with respect to the environment and cultures. The importance of local communities from rural areas and their right for sustainable tourism development are well-established. However, the Covid19 pandemic caused a rapid decline of tourist movement and uncertainty of recovery of the tourism economy. The research for this study was conducted via survey questionnaire, which was distributed to hospitality objects in rural areas of the West Serbia tourist region. In addition to the general information, the questionnaire comprised a set of questions related to tourists and perspectives perceived by the service providers. The research objectives are identification of the current consequences of the pandemic and comparison of business of hospitality objects in rural tourism before and during the Covid19 pandemic, by taking into consideration the principles of sustainability. The research results are expected to indicate a growing role of domestic tourism during the pandemic, as well as the perspectives of survival of certain hospitality objects. From the methodological perspective, quantitative and qualitative presentation of the data will provide an insight into the biggest and smallest challenges faced by the rural tourism in the studied area, which will provide practical implications for the subjects within the tourist offer of this part of Serbia.
\end{abstract}

Keywords: sustainability, rural tourism, Covid19, West Serbia.

\footnotetext{
${ }^{1}$ orcid.org/0000-0002-9117-270X, e-mail: marina.vesic@gef.bg.ac.rs

${ }^{2}$ orcid.org/0000-0001-9289-7684, e-mail: trifunovic.jeca89@gmail.com

3orcid.org/0000-0002-8688-5828, e-mail: nikolatodorovic.gef@gmail.com

${ }^{4}$ orcid.org/0000-0002-9596-8393, e-mail: sanja.pavlovic@gef.bg.ac.rs
} 


\section{UVOD / INTRODUCTION}

Održivost kao koncept razvijala se zajedno sa društvenim promenama (Galvani et al., 2020). Može se reći da je turizam jedna od privrednih delatnosti koje su najviše pogođene Covidom19 (Everingham, Chassagne, 2020). Pandemija Covid-19 uslovila je rapidno smanjenje turističkih kretanja i neizvesnost oporavka turističke privrede. U kontekstu trenutne situacije bilo je ideja da se ovaj period iskoristi za strukturne promene u turizmu, počevši od njegove održivosti (Romagosa, 2020). Chang et al. (2020) smatraju da svaku buduću krizu treba pretvoriti u priliku za održivost: praćenjem potencijalne turističke potražnje; davanjem prioriteta segmentima i predviđanje promena u turističkom ponašanju; garantovanje veza između potencijalnih posetilaca i odredišta; ponovnim pokretanjem turističke aktivnosti kako bi se maksimizirali ekonomski, socijalni i ekološki doprinosi; minimiziranjem negativnih uticaja ponovnog pokretanja turističke ekonomije.

Kao specifičan oblik turizma, ruralni turizam podrazumeva održivi, ekološki, ekonomski i socijalni razvoj (Tasić, 2018). Pozitivni efekti ruralnog turizma podrazumevaju uključenost i zaposlenost lokalnog stanovništva, dodatni prihod za seoska domaćinstva, razvoj proizvodnih i uslužnih delatnosti, zaštitu i očuvanje prirodne i kulturne baštine (Vujović i dr., 2020).

Prema Higgins-Desbiolles (2020), Covid-19 predstavlja priliku za promenu turizma ka održivosti i lokalnim interesima. Prirodne vrednosti će snažnije privući turiste nego ranije, jer oni žele da izbegnu gužvu i zagađene gradove (Spalding et al., 2020). U svemu ovome ističe se prednost ruralnog turizma.

Cilj ovog rada je identifikovati ruralni prostor turističke regije Zapadna Srbija kao atraktivnu, poželjnu i bezbednu turističku destinaciju, pre svega domaćim turistima, za vreme trajanja pandemije Covid-19. Istražiti stavove pružalaca ugostiteljskih usluga i zadovoljstva rezultatima njihovog poslovanja u nepredviđenim okolnostima, poput zdravstvene krize u čitavom svetu. Na osnovu toga, oceniti održivost turističkog poslovanja ruralnog prostora Zapadne Srbije.

\section{MATERIJALI I METODE / MATERIALS AND METHODS}

Istraživanje za potrebe ovog rada obavljeno je pomoću anketnog upitnika, koji je poslat na adrese ugostiteljskih objekata u ruralnim sredinama turističke regije Zapadna Srbija. Anketni upitnik je osim opštih informacija, sadržao set pitanja koja se odnose na turiste i perspektive sagledane sa aspekta pružalaca usluga, ocenjene kroz Likertovu skalu (1-5).
Primaran cilj istraživanja odnosio se na identifikaciju trenutnih posledica pandemije i upoređivanje poslovanja ugostiteljskih objekata u ruralnom turizmu pre i tokom pandemije Covida-19, uzimanjem u obzir principa održivosti. Izvršenom analizom podataka prikupljenih anketnim istraživanjem i obrađenih uz pomoć statističkog paketa za obradu podataka (SPSS 20.00), izdvojeni su oni rezultati koji su od značaja za temu istraživanja, izvršene dodatne analize i poređenja.

Postavljena je osnovna hipoteza 1 koja glasi: „Tokom trajanja pandemije Covida-19, u 2020. godini, došlo je do jačanja uloge domaćeg turizma (povećanja broja domaćih, a smanjenja ili gotovo potpunog izostanka inostranih turista) u ruralnim prostorima turističke regije Zapadna Srbija, u odnosu na ranije godine". U kontekstu ispitivanja održivosti formulisana je hipoteza 2: „Domaćinstva koja se bave turizmom na ovom prostoru smatraju da će se broj turista povećati u 2021. u odnosu na 2020. godinu".

\section{REZULTATI I DISKUSIJA / RESULTS AND DISCUSSION}

$U$ anketnom istraživanju je učestvovalo 42 ispitanika. Najbrojniji učesnici u anketi bila su domaćinstva iz opštine Požega, njih 11, sa učešćem od $26,19 \%$, Čajetina -8 domaćinstava $(23,81 \%)$, zatim Kosjerić - 6 domaćinstava sa udelom od $14,3 \%$. Domaćinstva iz ostalih opština u manjem obimu su se odazvala na anketu.

Među ispitanicima najstarije domaćinstvo posluje od 1973. godine i nalazi se na teritoriji opštine Ivanjica, u selu Lisa, a u pitanju je seosko turističko domaćinstvo sa najvišom kategorijom od $4^{*}$. Primetan je rast broja ugostiteljskih objekata koji su počeli sa radom od početka 21. veka, što je u skladu sa društveno-političkim promenama i dešavanjima u Srbiji, a koje su povoljno uticale na razvoj turizma. U poslednjih 5 godina, u periodu od 2015. do 2020. godine, među učesnicima ankete, registrovan je najveći broj ugostitljskih objekata koji su poslovanje u ugostiteljstvu započeli u 2017. godini (5 objekata). Takođe, po 4 objekta su poslovanje započela u 2015toj i 2016-toj, 3 u 2019-toj, 2 u 2018-toj, a interesantan je podatak da je 1 ugostiteljski objekat počeo sa radom baš u 2020. godini, kada je i započela pandemija virusa Covid-19.

Prema vrsti ugostiteljskih objekata kojima raspolažu domaćinstva u turizmu najveći broj među anketiranim su činila seoska turistička domaćinstva 18 (42,9\% u ukupnom uzorku), zatim apartmani - 9 (21,4\%), po 4 etno kuće i vile (udeo od po 9,5\%), 3 sobe $(7,1 \%)$ i po 1 - etno selo, konačište, nacionalna kuća, vajati (učešće od po 2,4\% u ukupnom uzorku). 


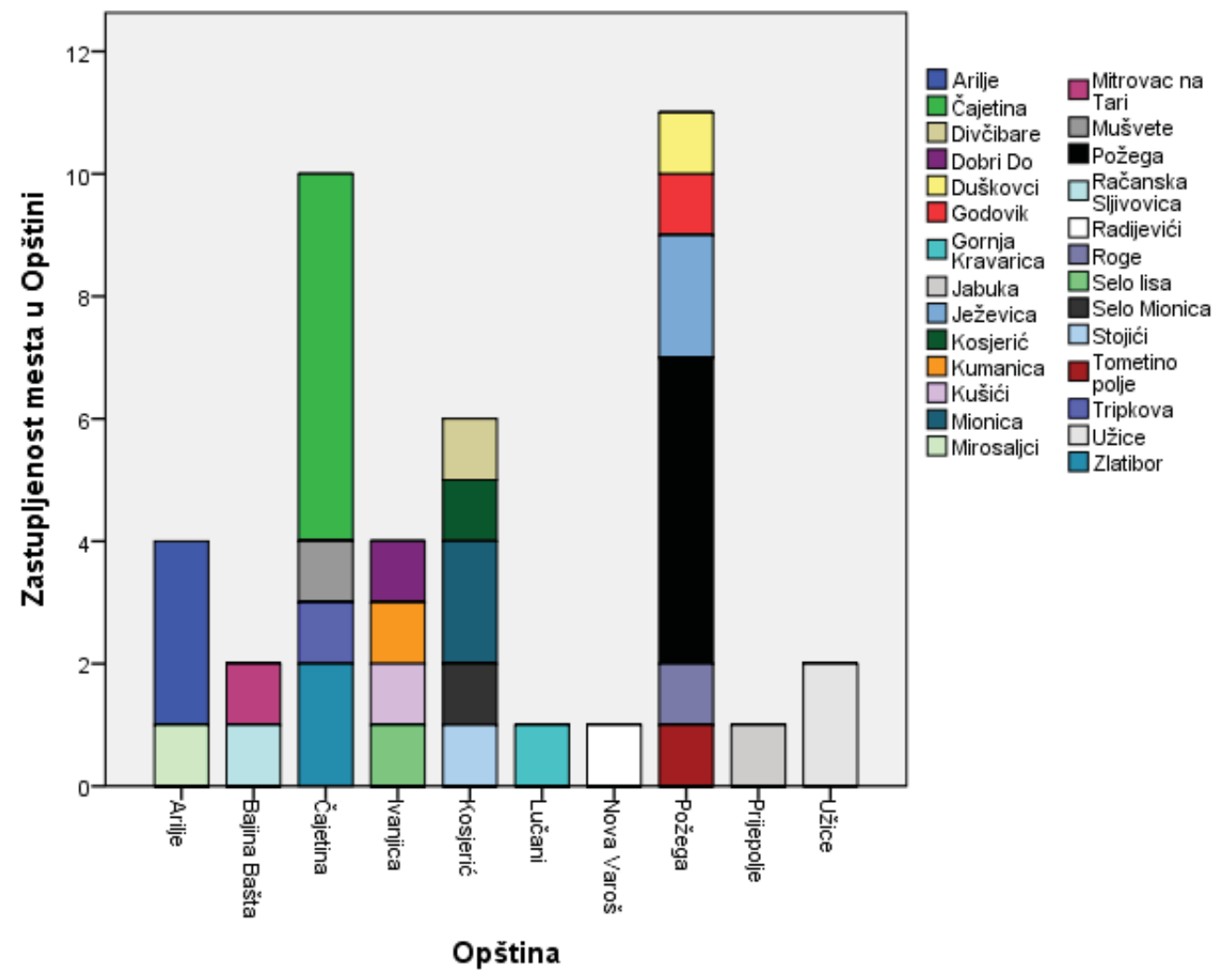

Grafikon 1 - Učešće u anketnom istaživanju naselja prema opštinama, u okviru turističke regije Zapadna Srbija Graph 1 - Participation in the survey of settlements by municipalities, within the tourist region of Western Serbia

Tabela 1 - Broj aktivnih seoskih turističkih domaćinstava 2020. godine u opštinama turističke regije Zapadna Srbija

Table 1 - The number of active rural tourist households in 2020 in the municipalities of the Tourist Region of Western Serbia

\begin{tabular}{|l|c|}
\hline Opština & $\begin{array}{c}\text { Broj aktivnih seoskih } \\
\text { turističkih domaćinstava } \\
\text { 2020. godine }\end{array}$ \\
\hline Arilje & 2 \\
\hline Bajina Bašta & 2 \\
\hline Ivanjica & 21 \\
\hline Kosjerić & 9 \\
\hline Nova Varoš & 7 \\
\hline Priboj & 0 \\
\hline Požega & 2 \\
\hline Prijepolje & 3 \\
\hline Čajetina & 30 \\
\hline Užice & 10 \\
\hline Ukupno & $\mathbf{8 6}$ \\
\hline
\end{tabular}

Izvor: Republički zavod za statistiku, Odeljenje Užice.

Kada je u pitanju ruralni turizam u Srbiji najveći broj smeštajnih kapaciteta imaju opštine Gornji Milanovac, Čajetina, Valjevo, Arilje, Kosjerić i Ljig (Gašić i dr., 2015). Među navedenih šest opština tri se nala- ze u turističkoj regiji Zapadna Srbija. Zanimljivo je istaći da su sela u opštini Ivanjica bila pioniri seoskog turizma u doba SFR Jugoslavije (Lakićević, Sagić, 2019), kao i sela u opštini Kosjerić.

Subvencije za izgradnju objekta i pružanje usluga u turizmu koristilo je $26,2 \%$ učesnika u anketi. Na pitanje: „Da li ste tokom pandemije dobili finansijsku pomoć od države", većina ispitanika je dala negativan odgovor (78,6\%), dok se svega $21,4 \%$ ispitanika izjasnilo da jeste. Ovo zapravo može biti odgovor, odnosno obrazloženje na pitanje koje je postavljeno vlasnicima ugostiteljskih objekata u trećem delu ankete koje se odnosi na perspektive, a koje je glasilo: „Zbog pandemije smo razmišljali da privremeno zatvorimo objekat", gde ocenjujući ovu tvrdnju stepenom slaganja od 1 do 5 (uopšte se ne slažem do potpuno se slažem), više od polovine ispitanika $(52,4 \%)$ se nije složilo sa datom tvrdnjom, njih $21,4 \%$ su imali neutralan stav (i složilo se i nije), dok se sa tvrdnjom složilo $26,2 \%$ ispitanika. Sa tvrdnjom: „Zbog pandemije smo razmišljali da prestanemo da se bavimo turizmom" složilo se $16,7 \%$ ispitanika, njih 14,3\% je bilo neodlučno, dok preostalih $69 \%$ nije imalo takvu nameru. $\mathrm{Na}$ osnovu ovakvog rezultatata možemo pretpostaviti da su se u brojnijoj grupi ispitanika, koji se nisu složili sa obe pomenute tvrdnje, odnosno raz- 
mišljali o privremenom zatvaranju svog objekta ili potpunom prestanku bavljenja turizmom, našli ispitanici koji su najverovatnije dobili neku vrstu finansijske pomoći od države za vreme trajanja pandemije Covida-19 (u 2020. godini) ili možda oni koji su koristili državne subvencije na početku svog osnivanja.

Autori Živković i dr. (2020) smatraju da je neophodno stvarati uslove za razvoj preduzetništva u turizmu, sa akcentom na održivoj poljoprivrednoj delatnosti. Kako bi se to obezbedilo neophodan je pristup izvorima finansiranja za mala i srednja preduzeća iz ovih delatnosti. Cilj održivog i uspešnog poslovanja jeste olakšati preduzetnicima obavljanje poslovanja. Međutim, rezultati dobijeni pri ovom istraživanju pokazuju da to nije tako, posebno u otežanim uslovima rada do kojih je dovela pandemija Covida-19. U finansiranje ruralnog turizma potrebno je uključiti pretpristupne fondove Evropske unije (IPARD), ali i potencijalne modalitete finansiranja, kao što su javno-privatna partnerstva, zajednička ulaganja, kao i njihovu aktivnu primenu u praksi (Radović, 2016; Radović i dr., 2018).
Među kategorizovanim objektima koji su učestvovali u anketnom istraživanju, najveći i zapravo podjednak broj je onih sa $2^{*}$ i $3^{*}$ (po $33,3 \%$ ). Imajući u vidu vrste ugostiteljskih objekata tipične za ruralne prostore, a prema važećem Pravilniku za kategorizaciju ugostiteljskih obejekata u Srbiji (2016), jasno je da kategorizacije kod ovih ugostiteljskih objekata idu do $4^{*}$ i ona je prisutna kod 9 objekata koji su učestvovali u ovom istraživanju, sa udelom od $21,4 \%$ u ukupnom uzorku, dok je samo 1 objekat imao najnižu kategoriju $-1^{*}$. Nekategorizovanih objekata, koji su učestvovali u istraživanju, bilo je 4 , čineći $9,5 \%$ u ukupnom uzorku.

Najveći broj učesnika u anketi u sastavu svojih ugostiteljskih objekata ima u ponudi po 5 i 6 ležaja (po $14,29 \%$ ). U globalu posmatrano, odnosno u ukupnom uzorku, procentualno je najveći broj ispitanika u kategoriji do 15 ležaja (83,33\%), između 15 i 30 ležaja ima $14,29 \%$ i samo jedan ugostiteljski objekat koji je učestvovao u anketi ima 64 ležaja u ponudi i učestvuje sa $2,38 \%$ u ukupnom uzorku (Grafikon 2).

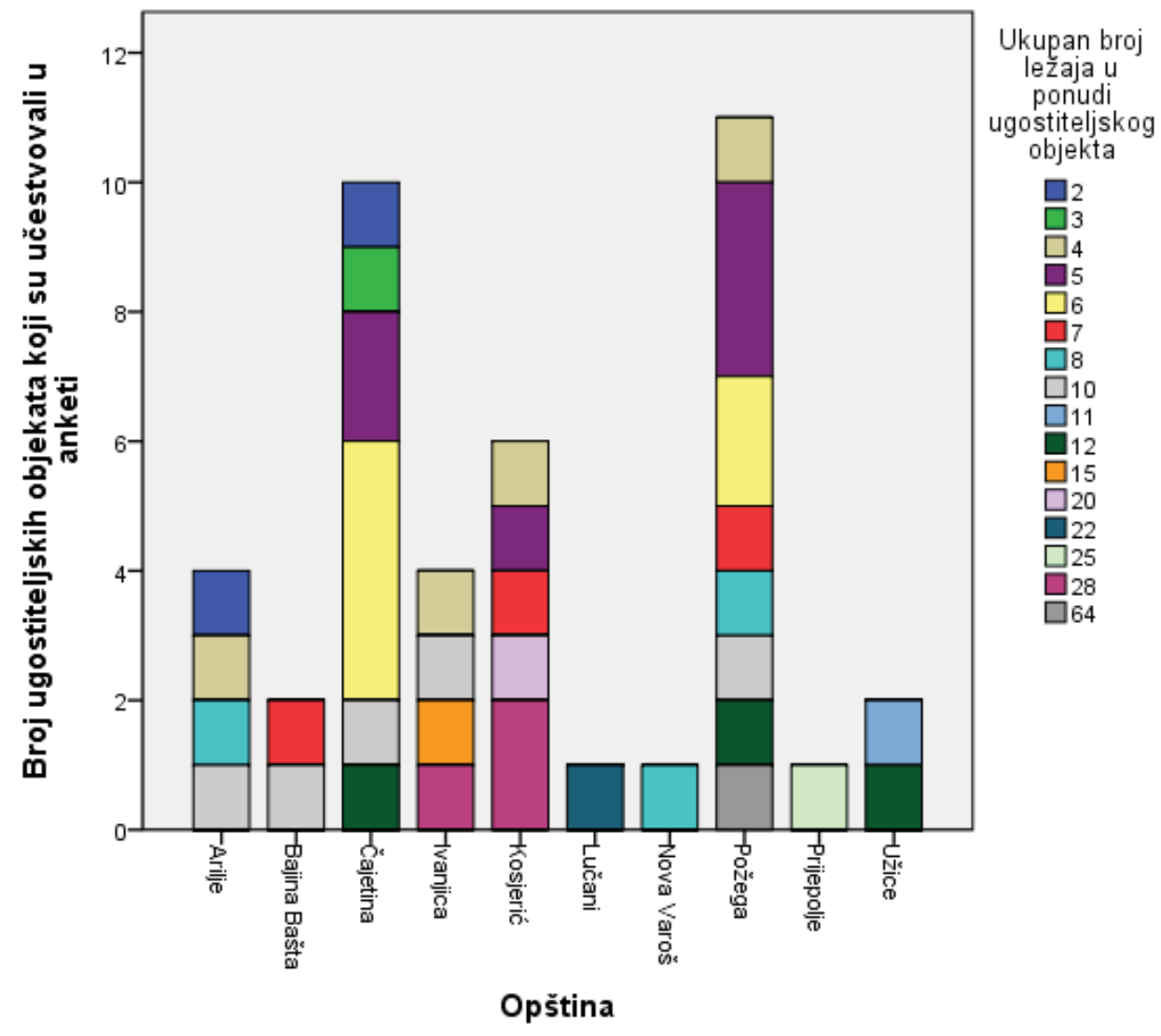

Grafikon 2 - Ukupan broj ležaja u okviru ugostiteljskih objekata, prema opštinama u ruralnom prostoru turističke regije Zapadna Srbija, koji su učestvovali u anketnom istraživanju

Graph 2 - Total number of beds within catering facilities, by municipalities in the rural area of the Tourist Region of Western Serbia, which participated in the survey 
U drugom delu ankete postavljena su pitanja i prikupljeni odgovori o turistima - gostima ugostiteljskih objekata u ruralnim sredinama turističke regije Zapadna Srbija.

Posmatrajući period pre pandemije, došlo se do sledećih podataka o turistima:

- u pogledu strukture turista dominantni su bili turisti srednje starosne dobi $(78,6 \%)$, koji su većinski boravili u pratnji porodice ili partnera $(83,3 \%)$. Sa prijateljima je boravilo $(9,5 \%)$, dok su ostalih $7,2 \%$ činili turisti koji su boravili ili sami ili preko organizovanih tura (đačke i studentske ekskurzije, penzionerski klubovi i sl.);

- prosečna potrošnja koju su turisti ostvarili (koristeći usluge smeštaja $i$ ishrane ili drugih proizvoda iz domaće radinosti) prema proceni većine ispitanika, kretala se do 100 eura (59,5\%), samo $2,4 \%$ ispitanika je odgovorilo da je prosečna potrošnja iznosila preko 500 eura;

- skoro polovina ispitanika $(47,6 \%)$ je odgovorila da na godišnjem nivou ima manje od 100 turista, dok je samo 7,1\% odgovorilo da ima preko 1.000 turista.

Istraživanje koje su ranije obavili Gajić et al. (2017) u ruralnim prostorima Srbije pokazuje da najveći procenat posetilaca ostaje pet $(63 \%)$ i sedam dana $(26 \%)$. U ovo stanovište se uklapaju posetioci ruralnih oblasti turističke regije Zapadna Srbija, koji većinom borave od dva do pet dana $(71,4 \%)$, uz dominaciju letnje sezone sa učešćem oko $88 \%$.

Imajući u vidu pretpostavku da će domaći turisti velikim delom provesti godišnje odmore u zemlji, početkom 2020. godine pojačane su onlajn aktivnosti, broj objava i komunikacija sa pratiocima, a početkom leta je počela i posebna kampanju koja je imala za cilj promociju ruralnog turizma u Regiji. Objavljeno je tri puta više sadržaja na Fejsbuku i Instagramu i, u saradnji sa lokalnim turističkim organizacijama (članicama Regionalne turističke organizacije), omogućeno je pratiocima ne samo da dodatno upoznaju lokalitete, već i da lakše dobiju informacije o smeštaju u domaćinstvima koja su tokom pandemije bila izuzetno popularna.

Sprovedenim istraživanjima za potrebe ovog rada je utvrđeno da svoju turističku ponudu, odnosno ugostiteljske objekte, ispitanici većinski promovišu putem društvenih mreža $(83,3 \%)$, zatim putem turističke agencije i organizacije $(59,5 \%)$ i preko rezervacione platforme (Booking, Airbnb i sl.) $(47,6 \%)$. Ostali načini promocije (tradicionalni mediji, sajmovi, brošure, ostali štampani materijal, gostoprimstvo i reklama „od usta do usta”) imali su udeo manji od $10 \%$. Ispitanici su kod ovog pitanja imali mogućnost da označe više ponuđenih odgovora ukoliko su bili od značaja za njih. Da imaju sopstveni sajt i da se reklamiraju putem njega istaklo je manje od polovine ispitanika $(35,7 \%)$.

U sličnim istraživanjima koja su se odnosila na ruralni turizam, rezultati su pokazali da većina turista smeštaj, prevoz i dodatne sadržaje na destinaciji rezerviše preko interneta. $U$ tome prednjače kineski turisti (Jerkić i dr., 2019). Budući da su tokom pandemije Covid-19 globalno izostale aktivnosti dizajnirane za promociju međunarodnog turizma (Yeh, 2020), jasno je zašto su gotovo svuda u svetu brojniji bili domaći nego inostrani turisti.

Prema rezultatima anketnog istraživanja, u periodu pre početka pandemije, odnosno do 2020. godine, podaci pokazuju da su podjednako bili zastupljeni i domaći i inostrani turisti $(50 \%)$. Da su brojniji bili domaći turisti navelo je $45,2 \%$ ispitanika, dok je svega $4,8 \%$ navelo da su među njihovim gostima brojniji bili inostrani turisti. Kao najbrojniji inostrani turisti evidentirani su: Rusi, Francuzi, Nemci, Kinezi, zatim turisti iz zemalja iz okruženja: Crnogorci, Rumuni, Bugari, Mađari, Bosanci i Hercegovci, ali i Slovenci, Poljaci, Englezi, Holanđani, Belgijanci, Španci, Amerikanci, Kanađani, Australijanci, Japanci. Odgovori upućuju na raznovrsnu strukturu inostranih turista, međunarodne kontraktivne zone.

Dostupni statistički podaci koji ukazuju na evidentirani turistički promet u godini pre i tokom pandemije Covid-19 (Tabele 2 i 3), pokazuju sledeće stanje u turizmu prostora turističke regije Zapadna Srbija.

Poređenje podataka o broju turista u opštinama turističke regije Zapadna Srbija pokazuje da je u 2020. broj turista bio 1,7 puta manji u odnosu na 2019. godinu. Broj domaćih turista je smanjen za 1,4 puta, a stranih 3,8 puta. $U$ opštini Čajetina 1,5 puta, $u$ Bajinoj Bašti 2,4 puta, u Požegi 2 puta, u Novoj Varoši 1,6 puta itd. Ukupan broj noćenja je smanjen za 1,5 puta (domaćih turista za 1,4 puta, stranih 3 puta). $U$ opštini Čajetina 1,4 puta, Bajinoj Bašti 2,5 puta, u Požegi 1,7 puta, Novoj Varoši 1,5 puta (Republički zavod za statistiku, Odeljenje Užice - prvi rezultati).

Navedeni podaci ukazuju da hipotezu 1 treba delimično prihvatiti jer, broj domaćih turista i njihovih noćenja nije porastao u 2020. godini u odnosu na 2019. godinu, a kada je u pitanju broj inostranih turista i njihovih noćenja broj je značajno smanjen, ali oni nisu izostali (Tabele 2 i 3 ).

Suprotno od našeg, u istraživanju koje su sproveli Vaishar \& Št'astná (2020), o uticaju pandemije Covida-19 na turizam u ruralnim područjima Češke, rezultati pokazuju da su neke ruralne destinacije u Češkoj zabeležile porast turizma u 2020. godini (posebno tokom letnje sezone), u poređenju sa 2019. godinom. 
Tabela 2 - Turisti i noćenja u opštinama turističke regije Zapadna Srbija (2019. godina)

Table 2 - Tourists and overnight stays in municipalities of the tourist region Western Serbia (2019)

\begin{tabular}{|l|c|c|c|c|c|c|}
\hline \multirow{2}{*}{ Opština } & \multicolumn{3}{|c|}{ dolasci turista } & \multicolumn{3}{c|}{ noćenja turista } \\
\cline { 2 - 7 } & ukupno & domaći & strani & ukupno & domaći & strani \\
\hline UKUPNO & $\mathbf{4 0 9 5 1 4}$ & $\mathbf{3 0 5 6 2 5}$ & $\mathbf{1 0 3 8 8 9}$ & $\mathbf{1 3 3 9 8 6 3}$ & $\mathbf{1 1 1 3 4 3 9}$ & $\mathbf{2 2 6 4 2 4}$ \\
\hline Arilje & 1354 & 990 & 364 & 2244 & 1600 & 644 \\
\hline Bajina Bašta & 49364 & 45548 & 3816 & 212560 & 203494 & 9066 \\
\hline Ivanjica & 20910 & 18514 & 2396 & 93206 & 85122 & 8084 \\
\hline Kosjerić & 1294 & 926 & 368 & 3804 & 2309 & 1495 \\
\hline Nova Varoš & 18598 & 16682 & 1916 & 58469 & 55003 & 3466 \\
\hline Požega & 13171 & 7703 & 5468 & 24876 & 17442 & 7434 \\
\hline Priboj & 4368 & 2859 & 1509 & 20264 & 13553 & 6711 \\
\hline Prijepolje & 1866 & 1390 & 476 & 2898 & 2022 & 876 \\
\hline Užice & 59760 & 41505 & 18255 & 137827 & 108673 & 29154 \\
\hline Čajetina & 238829 & 169508 & 69321 & 783715 & 624221 & 159494 \\
\hline
\end{tabular}

Izvor: Republički zavod za statistiku, Odeljenje Užice (prvi rezultati)

Tabela 3 - Turisti i noćenja u opštinama turističke regije Zapadna Srbija (2020. godina)

Table 3 - Tourists and overnight stays in municipalities of the tourist region Western Serbia (2020)

\begin{tabular}{|l|c|c|c|c|c|c|}
\hline \multirow{2}{*}{ Opština } & \multicolumn{3}{|c|}{ dolasci turista } & \multicolumn{3}{c|}{ noćenja turista } \\
\cline { 2 - 7 } & ukupno & domaći & strani & ukupno & domaći & strani \\
\hline UKUPNO & $\mathbf{2 4 6 3 0 1}$ & $\mathbf{2 1 8 7 9 7}$ & $\mathbf{2 7 5 0 4}$ & $\mathbf{8 9 0 5 7 7}$ & $\mathbf{8 1 3 6 8 8}$ & $\mathbf{7 6 8 8 9}$ \\
\hline Arilje & 876 & 805 & 71 & 1788 & 1701 & 87 \\
\hline Bajina Bašta & 20489 & 19710 & 779 & 86234 & 84815 & 1419 \\
\hline Ivanjica & 11051 & 10446 & 605 & 48501 & 46595 & 1906 \\
\hline Kosjerić & 750 & 705 & 45 & 1667 & 1551 & 116 \\
\hline Nova Varoš & 11642 & 11364 & 278 & 37966 & 37314 & 652 \\
\hline Požega & 6682 & 5806 & 876 & 14551 & 12921 & 1630 \\
\hline Priboj & 2468 & 2411 & 57 & 11252 & 11123 & 129 \\
\hline Prijepolje & 1224 & 1055 & 169 & 2106 & 1866 & 240 \\
\hline Užice & 33482 & 30570 & 2912 & 110804 & 104759 & 6045 \\
\hline Čajetina & 157637 & 135925 & 21712 & 575708 & 511043 & 64665 \\
\hline
\end{tabular}

Izvor: Republički zavod za statistiku, Odeljenje Užice (prvi rezultati)

U trećem delu anketnog upitnika, formulisane su tvrdnje koje mogu ukazati na perspektive poslovanja ugostiteljskih objekata u ruralnim sredinama turističke regije Zapadna Srbija. Ispitanicima je ostavljen izbor da ocenom od 1 do 5 na Likertovoj skali iskažu svoj stav u intervalu od potpunog neslaganja do potpunog slaganja sa datim tvrdnjama.

Često se tvrdi da sektor turizma ima visoku otpornost i prilagodljivost neočekivanim pojavama, kao i mogućnost da se oporavi od njih (Romagosa, 2020). Da je zadovoljno svojim poslovnim rezultatima ostvarenim pre pandemije Covida-19, uglavnom i u potpunosti se složilo $61,9 \%$ ispitanika. Očekivanja da će broj turista biti veći u 2021. u odnosu na 2020. godinu izrazilo je $50 \%$ ispitanika, $21,4 \%$ je imalo neutralan stav, dok je sumnju u to imalo $28,6 \%$ ispitanika, čime je hipoteza 2 koja glasi: „Domaćinstva koja se bave turizmom na ovom prostoru smatraju da će se broj turista povećati u 2021. u odnosu na 2020. godinu", delimično prihvaćena. Jedan od pokazatelja mogućeg porasta broja turista je prihvatljiva cena usluga, što je mišljenje gotovo svih ispitanika $(95,2 \%)$.

Da se bave turizmom prvenstveno iz ekonomskih razloga složilo se $50 \%$ ispitanika, dok se njih $23,8 \%$ nije složilo sa tom tvrdnjom, a njih $26,2 \%$ je imalo neutralan stav. Gotovo svi ispitanici su se složili da se turizmom bave zato što uživaju u tome $(83,3 \%)$, neslaganja nije bilo, a neutralan stav je imalo 16,7\%. Da je bavljenje turizmom porodična tradicija izjasnilo se $33,4 \%$ ispitanika, $9,5 \%$ je imalo neutralan stav, dok se $57,1 \%$ ispitanika nije složio sa datom tvrdnjom.

Zadovoljstvo prihodom od turizma u 2020. godini (tokom pandemije virusa Covid-19) iskazalo je 31,7\% ispitanika, isto toliko ispitanika je imalo neutralan stav, dok malo preko jedne trećine ispitanika nije bilo zadovoljno ostvarenim prihodom. Iznosom finansijske pomoći, koju su dobili od države u 2020. godini, nije bila zadovoljna većina ispitanika (83,4\%), 9,5\% je 
imalo neutralan stav (i bilo je zadovoljno i ne), dok je svega $7,1 \%$ ispitanika izrazilo zadovoljstvo.

Više od polovine ispitanika $(52,4 \%)$ se složilo sa tvrdnjom da je pandemija dovela do ozbiljnog smanjenja broja gostiju u njihovom ugostiteljskom objektu. Međutim, da su zbog otežanog načina rada i nedovoljno finansijskih sredstava za dalje bavljenje ovom delatnošću razmišljali o tome da privremeno zatvore svoj ugostiteljski objekat složilo se svega $26,2 \%$, njih $21,4 \%$ su imali neutralan stav, dok više od polovine ispitanika $(52,4 \%)$ nije imalo takvu nameru. Da u potpunosti prestanu da se bave turizmom razmišljalo je $16,7 \%$, njih $14,3 \%$ je bilo neodlučno, dok preostalih $69 \%$ ponovo nije imalo takvu nameru.

Da imaju mogućnost potpunog sprovođenja epidemioloških mera složilo se $90,5 \%$ ispitanika. Zabrinutost da se bave turizmom, odnosno strah da neko od gostiju može da ih zarazi Covidom-19 izrazilo je $21,5 \%$ ispitanika, dok je $16,7 \%$ je imalo neutralan stav. Saglasnost sa tvrdnjom da je veća šansa da zarazu zaposlenima donesu turisti iz inostranstva nego domaći turisti iskazalo je samo $2,4 \%$, neopredeljeno je bilo $31 \%$ ispitanika, dok preostali ispitanici nisu bili takvog mišljenja.

Prema mišljenju većine ispitanika $(96,3 \%)$, u 2020. godini turisti su kod njih dolazili (birali ruralne prostore) jer su se osećali bezbednije od virusa. Takođe, da je gostima zdravstvena bezbednost bila veoma bitna tokom boravka u njihovom ugostiteljskom objektu složilo se $83,3 \%$ ispitanika, koji su uočili da su gosti uglavnom bili više zainteresovani za sam boravak u prirodi $(88,2 \%)$ i ostvaren minimalan kontakt sa njima kao domaćinima $(54,8 \%)$. Boravak u prirodi je obogaćen realizacijom projekata turističke regije Zapadna Srbija, koji su podrazumevali pešačke i biciklističke staze, postavljanje informativnih i putokaznih tabli. Većina ispitanika se složila da su turisti minimalan kontakt ostvarivali i sa drugim lokalnim stanovništvom (64,2\%).

\section{ZAKLJUČAK / CONCLUSION}

lako je bilo očekivano da ruralni prostori i prirodne sredine budu „utočište” velikom broju, pre svega domaćih, turista u toku pandemije Covid-19, statistički podaci su pokazali da u turističkoj regiji Zapadna Srbija, nije došlo do povećanog obima turističkih kretanja. Bez obzira na to pružaoci usluga u ruralnom turizmu optimistični su kada je u pitanju perspektiva njihovog opstanka. Subvencije za bavljenje turizmom koristio je mali broj ispitanika, ali bi one mogle biti podstrek za jačanje ruralnog turizma ovog prostora. Finansijska pomoć države u vreme pandemije takođe je uglavnom izostala, zbog čega su pojedina domaćinstva razmišljala privremeno ili potpuno da prekinu aktivnosti u turizmu. Najavljena mera državne pomoći turizmu i sektoru ugostiteljstva sigurno bi uticala na jačanje samopouzdanja pružalaca usluga i njihov održivi ekonomski (finansijski) razvoj.

Istraživanje je, takođe pokazalo, da su pružaoci usluga spremni i voljni za rad i u otežanim uslovima, da su obezbedili sve moguće mere zdravstvene zaštite koje mogu da garantuju bezbednost turista. U tom smislu možemo govoriti o izraženom ekološkom aspektu i njegovoj održivosti, budući da su turisti u ruralnim sredinama većinski provodili vreme u prirodi i u krugu ljudi sa kojima su doputovali. Međutim, samim tim, u isto vreme dolazi do izražaja sociokulturni aspekt, odnosno odnosi i uticaji komunikacije na relaciji domaćin-gost, koji su opravdano, gotovo u potpunosti izostali, a koje ne treba zanemariti u perspektivi, već težiti da se nađe neko kompromisno rešenje za njihovu održivost.

\section{LITERATURA / REFERENCES}

[1] Chang, C.L., McAleer, M., Ramos, V. (2020). A Charter for Sustainable Tourism after COVID-19. Sustainability, 12, 3671, doi:10.3390/su12093671

[2] Everingham, P., Chassagne, N. (2020). Post COVID-19 ecological and social reset: moving away from capitalist growth models towards tourism as Buen Vivir. Tourism Geographies, 22(3), 555-566, DOI:10.1080/14616688.2020.1762119

[3] Gajić, T., Vujko, A., Penić, M., Petrović, M., Mrkša, M. (2017). Significant involvent of agricultural holdings in rural tourism development in Serbia. Economics of Agriculture, 64(3), 901-918.

[4] Galvani, A., Lew, A.A., Sotelo Perez, M. (2020). COVID-19 is expanding global consciousness and the sustainability of travel and tourism. Tourism Geographies, DOI:10.1080/14616688.2020.1760924

[5] Gašić, M., Perić, G., Ivanović, V. (2015). Razvijenost ruralnog turizma u Republici Srbiji. BizInfo (Blace), 6(2), 71-81. https://doi.org/10.5937/BIZINFO1502071G

[6] Higgins-Desbiolles, F. (2020). Socialising tourism for social and ecological justice after COVID-19. Tourism Geographies. https://doi.org/10.1080/14616688.2020.1757748

[7] Jerkić, T., Okanović, A., Vukadinović, S. (2019). Značaj ruralnog turizma za privlačenje kineskih turista u Srbiju. Ecologica, 26(96), 469-474.

[8] Lakićević, M., Sagić, Z. (2019). Accomodation capacities and their utilization in the function of tourism development: case of Ivanjica. Економика, 65(3), 77-88. 
[9] Pravilnik o standardima za kategorizaciju ugostiteljskih objekata za smeštaj. (2016), Službeni glasnik RS., br. 83/2016.

[10] Radović, G. (2016). Sources of finance for rural tourism in the Republic of Serbia. Economics of Agriculture, 63(3),1053-1065.

[11] Radović, G., Košić, K., Demirović, D. (2018). Financing as a key factor of the strategy of sustainable rural tourism development in the Republic of Serbia. Economics of Agriculture, 65(1), 413426. doi:10.5937/ekoPolj1801413R

[12] Republički zavod za statistiku, Odeljenje Užice (prvi rezultati). (2019, 2020).

[13] Romagosa, F. (2020). The COVID-19 crisis: Opportunities for sustainable and proximity tourism. Tourism Geographies, DOI:10.1080/14616688.2020.1763447

[14] Spalding, M., Burke, L., Fyall, A. (2020). Covid19: implications for nature and tourism. Anatolia, DOI: 10.1080/13032917.2020.1791524
[15] Tasić, J. (2018). Budući trendovi i pravci razvoja ruralnog turizma u Srbiji i u svetu. Oditor, 4(3), 7 19. doi:10.5937/Oditor1803007T

[16] Vaishar, A., Št'astná, M. (2020). Impact of the COVID-19 pandemic on rural tourism in Czechia Preliminary considerations. Current Issues in Tourism, DOI: 10.1080/13683500.2020.1839027

[17] Vujović, S., Premović, J., Arsić, Lj. (2020). Ekološki aspekti materijalne osnove ruralnog turizma. Ecologica, 27(97), 65-69.

[18] Yeh, S.S. (2020). Tourism recovery strategy against COVID-19 pandemic. Tourism Recreation Research, DOI:10.1080/02508281.2020.1805933

[19] Živković, D., Petrović, P., Ercegović, M. (2020). Način finansranja malih i srednjih preduzeća u hotelijerstvu i eko-turizmu. Ecologica, 27(97), 7581. 